\title{
PENERAPAN DUKUNGAN TEMPAT KERJA PADA IBU MENYUSUI DENGAN PERILAKU PEMBERIAN ASI EKSKLUSIF DI KECAMATAN MARGADANA
}

\author{
Evi Zulfiana ${ }^{1}$, Meyliya Qudriani, ${ }^{2}$ \\ Email : evi.zulfiana33@gmail.com \\ ${ }^{1,2}$ Program Studi D III Kebidanan Politeknik Harapan Bersama \\ Jl.Mataram no.09 Pesurungan Lor Kota Tegal Telp (0283) 352000
}

\begin{abstract}
Abstrak
ASI Eksklusif merupakan ASIyang diberikan dari seorang ibu kepada si kecil dari bayi lahir sampai usia 6 bulan. tahun 2017 jumlah bayi 557. Dimana dari 557 bayi hanya 167 (30\%) yang mendapatkan ASI Eksklusif dan 390 (70\%) yang tidak mendapatkan ASI Eksklusif. capaian tersebutbelum sesuai dengan target nasional 85\%. Tujuan penelitian untuk mengetahui Pengaruh Dukungan Tempat Kerja PadaIbu Meyusui Dengan Perilaku Pemberian ASI Eksklusif di Kecamatan Margadana Tahun 2017. Responden pada penelitian ini adalah ibu bekerja dan menyusui bayinya umur 7 bulan - 12 bulan di Kecamatan Margadana Kota Tegal. Jenis penelitian ini adalah Analitik dengan rancangan pendekatan Cross Sectional. Teknik sampel menggunakan acsidental sampling dengan sampel yaitu 37 responden. Hasil penelitian Sebagian besar karakteristik responden di kecamatan Margadana Kota Tegal tahun 2017, berdasarkan umur 20-35 tahun $(81,1 \%)$, pendidikan SMA $(64,9 \%)$, pekerjaan pegawai swasta $(91,9 \%)$, paritas multipara (54,1\%). Dukungan tempat kerja baik $(59,5 \%)$. hasil uji statistik dengan Chi Square diperoleh nilai $\mathrm{x}^{2}$ hitung sebesar 10,917 dengan $\rho$ value 0,004 . Nilai $\mathrm{x}^{2}$ tabel pada $\mathrm{df}=2$ adalah 5,99. Oleh karena $x^{2}$ hitung $>x^{2}$ tabel $(10,917>5,99)$ dengan $\rho(0,004<0,05)$, hal ini dapat diartikan Ada pengaruh Antara Dukungan Tempat Kerja Dengan Perilaku Pemberian ASI Eksklusif di Kecamatan Margadana Kota Tegal.
\end{abstract}

Kata Kunci :Dukungan Tempat Kerja, Perilaku

\section{Pendahuluan}

ASI merupakan nutrisi yang baik untuk bayi, sebab ASI mengandung semua zat gizi untuk membangun dan menyediakan energi dalam susunan yang diperlukan. ASI merupakan makanan utama bagi bayi yang kandungannya lemak dalam larutan protein, laktosa dan garam organic yang disekresi oleh kedua belah kelenjar payudara ibu. ${ }^{[1]}$

ASI Eksklusif harus diberikan pada bulan-bulan pertama setelah kelahiran bayi, pada fase ini terjadi pertumbuhan, pembentukan dan akulturasi yang cepat. ASI Eksklusif adalah pemberian ASI dari seorang ibu kepada si kecil dari lahir sampai dengan usia bayi 6 bulan tanpa tambahan makanan apapun. ${ }^{[2]}$

Salah satu kegagalan pemberian ASI Eksklusif adalah pengetahuan dan dukungan tempat kerja, pengetahuan dan dukungan tempat kerja merupakan Predisposing factor (faktor pendorong) yang akan mempengaruhi perilaku seseorang. ${ }^{[3]}$

Faktor pengetahuan ibu maupun keluarga sangat mendukung proses pemberian ASI Banyak keluhan ibu menyusui bahwa anaknya tidak sabaran, ibu mengatakan air susunya tidak keluar. Hal ini dapat terjadi dan sering terjadi di masyarakat, begitu pula ibu menyusui yang juga harus meninggalkan rumah untuk bekerja. Sebenarnya apa yang dikeluhkan dapat dicegah, apabila mengetahui penyebabnya. ${ }^{[4]}$

Bagi ibu yang bekerja, belum banyak tempat kerja yang mempunyai pojok laktasi, sebaiknya walaupun tidak ada atau belum ada, ibu bisa melakukannya diruangan yang bisa dimanfaatkan untuk memerah, dan kalau sangat terpaksa bisa dilakuakan di toilet.

ASI Eksklusif mendapat dilegitimasi dalam Undang-Undangkesehatan bahwa bayi berhak mendapatkan ASI secara eksklusif selama 6 bulan terkecuali ada indikasi medis. Dukungan keluarga, pemerintah, pemerintah daerah dan masyarakat sangat dibutuhkan oleh ibu selama menyusui bayiny dan dukungan ditempat kerja dalam penyediaan fasilitas husus. Surat Kepmenkes No 450 tahun 2004 tentang Pemberian ASI secara Eksklusif, Pemerintah melalui Kementerian Kesehatan 
telah mengeluarkan kebijakan terkait peraturan pemberian ASI Eksklusif di tempat kerja. ${ }^{[5]}$

Kota tegal memiliki cakupan Asi Eksklusif yang rendah 23,8\%. Data yang didapatkan dari Puskesmas margadana tahun 2016 terdapat 215 bayi. Dimana dari 215 bayi hanya $59.1 \%$ (127 bayi) bayi yang berhasil mendapatkan ASI secara eksklusif18.1\% (39 bayi) masih dalam tahap pemberian ASI Eksklusif dan 22,8\% (49 bayi) tidak mendapat Asi Eksklusif.tahun 2017 terdapat 557 bayi. Dimana dari 557 bayi hanya 167 (30\%) yang mendapatkan ASI Eksklusif dan 390 (70\%) yang tidak mendapatkan ASI Eksklusif. capaian tersebut sangat jauh dari target nasional 85\%.(Dinkes Tegal, 2016) ${ }^{[6]}$

\section{Metode Penelitian}

Penelitian menggunakan analitik dimana peneliti tidak hanya mendeskripsikan saja tetapi sudah menganalisis hubungan antar variabel.kriteria sampel pada penelitian ini adalah ibu bekerja yangmenyusui bayinya umur 7 bulan -12 bulan. pengambilan sampel dilakukan dengan acsidental sampling yaitu pengambilan sampel secara aksidental (accidental) dengan mengambil kasus atau responden yang kebetulan ada atau tersedia di suatu tempat sesuai dengan konteks penelitian. Penelitian dilakukan dengan membagikan kuesioner dan dianalisis. ${ }^{[7]}$

\section{Hasil dan Pembahasan}

Hasil penelitian disajikan dalam analisis univariat dan analisis bivariat untuk mengetahui penerapan dukungan tempat kerja padaibu menyusui dengan perilaku pemberian asi eksklusif.

Berdasarkan table 1 menunjukan bahwa sebagian besar responden berumur 20-35 tahun 30 responden, pendidikan SMA 24 responden, pekerjaan pegawai swasta 34 responden dan sebagian besar responden mempunyai anak $2-4$.

Tabel 1. Karakteristik Responden berdasarkanumur, pendidikan, pekerjaandan paritas

\begin{tabular}{llcc}
\hline Variabel & \multicolumn{1}{c}{$\begin{array}{c}\text { Sub } \\
\text { Variabel }\end{array}$} & $\begin{array}{c}\text { Frekue } \\
\text { nsi }\end{array}$ & $\begin{array}{c}\text { Prosentas } \\
\text { e (\%) }\end{array}$ \\
\hline Umur & $\begin{array}{c}c \\
\text { 20 tahun }\end{array}$ & 1 & 2,7 \\
& $\begin{array}{l}20- \\
\text { tahun }\end{array}$ & 30 & 81,1 \\
& $>35$ tahun & 6 & 16,2 \\
& & \\
\hline Pendidikan & SD & 0 & 0 \\
& SMP & 0 & 0 \\
& SMA & 24 & 64,9 \\
& Perguruan & 13 & 35,1 \\
& tinggi & & \\
\hline Pekerjaan & PNS & 3 & 8,1 \\
& TNI/POLRI & 0 & 0 \\
& Pegawai & 34 & 91,9 \\
& Swasta & 0 & 0 \\
& Wiraswasta & 0 & 0 \\
& Buruh & & \\
\hline Paritas & Primipara & 17 & 45,9 \\
& Multipara & 20 & 54,1 \\
& Grandemulti & 0 & 0 \\
& para & & \\
\hline
\end{tabular}

Tabel2. Distribusi frekuensi dukungantempat kerja dengan pemberian ASI Eksklusif diKecamatanMargadana Kota Tegal Tahun 2017.

\begin{tabular}{ccc}
\hline $\begin{array}{c}\text { Dukungan } \\
\text { Tempat } \\
\text { Kerja }\end{array}$ & Frekuensi & $\begin{array}{c}\text { Prosentase } \\
(\%)\end{array}$ \\
\hline Baik & 22 & 59,5 \\
Cukup & 8 & 21,6 \\
Kurang & 7 & 18,9 \\
\hline Jumlah & 37 & 100 \\
\hline
\end{tabular}

Pada table 2. Dapat dilihat bahwa dukungan tempat kerja dengan pemberian asi eksklusif baik sebanyak 22 responden.

Dukungan program ASI eksklusif oleh pengurus tempat kerja dan penyelenggara tempat sarana umum dilaksanakan sesuai dengan peraturan perusahaan dengan menyediakan fasilitas husus untuk menyusui / memerah ASI sesuai dengan kemampuan perusahaan. ${ }^{[8]}$

Berdasarkan Peraturan Menteri Kesehatan No 15 Tahun 2013 pasal 11 ayat 2 disebutkan bahwa penyimpanan ASI meliputi : lemari pendingin, cooler bag, dan Sterilizer botol.. ${ }^{[9]}$

Dapat disimpulkan bahwa besarnya dukungan tempat kerja responden, dimungkinkan karena Pimpinan tempat kerja menerapkan peraturan dan kebijakan pada pekerja wanita yang masih menyusui 
untuk memberikan ASI secara Eksklusif. Hal ini menunjukan ada kesesuaian antara hasil penelitian dan teori.

Tabel 3. Pengaruh dukungan tempat kerjadengan perilakupemberian ASI eksklusif di KecamatanMargadana Kota Tegal

Pemberian Dukungan Tempat Kerja $\mathrm{X}^{2}$
ASI Baik Cukup Kurang

$\mathrm{X}^{2}-\mathrm{AS}$

\begin{tabular}{cccccc}
\hline Ya & 21 & 7 & 3 & & \multirow{2}{5}{ 5. } \\
Tidak & 1 & 1 & 4 & & .004 \\
& & & & & \\
\hline Total & 22 & 8 & 7 & & \\
\hline
\end{tabular}

5. Daftar Pustaka

[1] Weni, Kristiyanasari. 2011. ASI, Menyusui \& Sadari. Yogyakarta: NuhaMedika

Penelitian pada 37 responden ibu bekerja yang menyusui bayinya 7 bulan -12 bulan paling banyak yaitu dukungan tempat kerja baikmemberikasn ASI Eksklusif 22 responden (59,5\%). Berdasarkan hasil uji statistik dengan Chi Square diperoleh nilai $\mathrm{x}^{2}$ hitung sebesar 10,917 dengan $\rho$ value 0,004 . Nilai $x^{2}$ tabel pada $d f=2$ adalah 5,99. Oleh karena $\mathrm{x}^{2}$ hitung $>\mathrm{x}^{2}$ tabel $(10,917>$ $5,99)$ dengan $\rho(0,004<0,05)$, hal ini dapat diartikan Ada pengaruh Antara Dukungan Tempat Kerja Dengan Perilaku Pemberian ASI Eksklusif di Kecamatan Margadana Kota Tegal.

Menurut Lawrence Green bahwa perilaku terbentuk dari 3 faktor, yakni : Predisposing Faktor (Faktor Predisposisi), Enabling Faktors (Faktor Pemungkin), Reinforcing Faktors (Faktor Penguat). ${ }^{[3]}$

Dapat disimpulkan bahwa hasil penelitian menunjukan Ada pengaruh Antara Dukungan Tempat Kerja Dengan Perilaku Pemberian ASI Eksklusif di Kecamatan Margadana Kota Tegal. Hal ini menunjukan ada kesesuaian antara hasil penelitian dan teori.

\section{Kesimpulan}

Penelitian dilakukan pada 37 responden ibu bekerja yang menyusui bayinya umur 7 bulan -12 bulan. hasil survey menunjukan sebagian besar umur responden 20-30 tahun, rata -rata pendidikan SMA, pekerjaan pegawai swasta dan responden sudah punyaanak 2-4.

Berdasarkan tabel diatas menunjukan bahwa dukungan tempat kerja dengan pemberian asi eksklusif baik sebanyak 22 responden.

Hasil penelitian yang dilakukan, dari 37 responden $i b u$ bekerja yang menyusui bayinya 7 bulan - 12 bulan diperoleh $\mathrm{x}^{2}$ hitung $=10,917$ dan $\rho$ value $=0,004$ yang artinya ada pengaruh antara dukungan tempat kerja dengan perilaku pemberian ASI eksklusif di Kecamatan Margadana valuKota Tegal tahun 2017.
[2] Nana, Aditya. 2014. Handbook for New Mom. Yogyakarta : Stiletto Book

[3] Titik, Lestari. 2015. Kumpulan Teori Untuk Kajian $P$ ustaka Penelitian Kesehatan. Yogyakarta: NuhaMedika

[4] Hesti, Widuri. 2013. Cara Mengelola ASI Eksklusif Bagi Ibu Bekerja. Yogyakarta: Gosyen Publishing

[5] Bambang, S. 2009. Undang - Undang RI No 36 Tahun 2009 Tentang Kesehatan. Jakarta

[6] Dinkes Kota Tegal, 2016. Cakupan Asi Eksklusif. Tegal

[7] Notoatodjo, Soekidjo. 2003. Promosi Kesehatan Teori dan Aplikasi. Jakarta: RinekaCipta

[8] Bambang, S. 2009. Peraturan pemerintah RI No 33 Tahun 2007 Tentang pemberian Air Susu Ibu Eksklusif. Jakarta

[9] Mboi Nafsiah. 2013. Peraturan mentri kesehatan RINo 15 Tahun 2013 tentang tata cara penyediaan fasilitas khusus menyusui dan/atau memerah air susu ibu. Jakarta 
